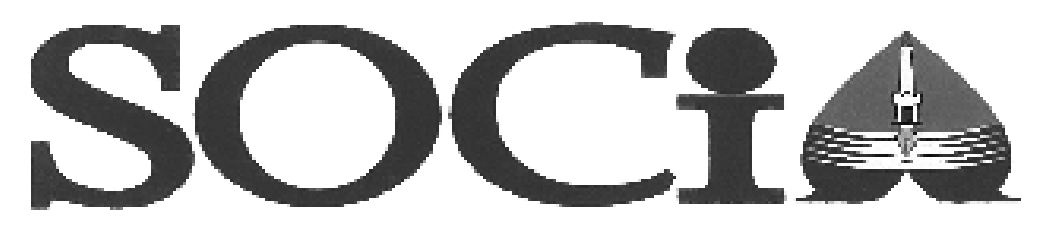

[p-ISSN] 1829-5797

(eISSN) $2549-9475$

J U R N A L I L M U - I L M U S O I A L

Mei 2017, Vol. 14, No. 1, hal 15-25

\title{
MEDIASI DALAM PENYELESAIAN SENGKETA KESEHATAN DI JOGJA MEDIATION CENTER
}

\author{
Setiati Widihastuti, Sri Hartini, dan Eny Kusdarini \\ Program Studi Pendidikan Kewarganegaraan dan Hukum FIS UNY \\ setiatiwidi@uny.ac.id
}

\begin{abstract}
Abstrak
Penelitian ini bertujuan untuk mengetahui faktor penyebab terjadinya sengketa kesehatan, dan menggambarkan cara mediator Jogja Mediation Center (JMC) mengupayakan perdamaian diantara para pihak yang bersengketa. Metode yang digunakan adalah deskriptif kualitatif. Wawancara dan studi dokumentasi dipilih sebagai teknik pengumpulan data. Subjek penelitian ditentukan dengan teknik purposive. Analisis data secara induktif, yang tahapannya terdiri dari reduksi data, unitisasi dan kategorisasi data, display data, kesimpulan serta verifikasi. Dalam simpulan penelitian ini dapat dikemukakan bahwa 1) terjadinya sengketa kesehatan disebabkan antara lain karena: kurang efektifnya komunikasi dalam menindaklanjuti ketidakpuasan pasien atas layanan dan tindakan medis yang diterimanya, serta meluasnya ketidakpuasan pasien sampai ke ranah publik dan media massa, 2) hampir semua sengketa kesehatan yang ditangani oleh mediator Jogja Mediator Center, bisa didamaikan dengan cara melakukan pendekatan psikologis pada para pihak yang bersengketa, mengadakan kaukus, memotivasi para pihak untuk hadir sendiri tanpa kuasa hukum dan melakukan manufer hukum dalam pembuatan akta perdamaian Kata kunci: sengketa kesehatan, mediasi, Jogja Mediation Center

\section{Abstrak}

This study aims to investigate the factors causing health disputes, and describe mediator method Jogja Mediation Center (JMC) strive for peace between the parties to dispute. The method used is qualitative descriptive. Interview and documentation study selected as data colletion technique. The Subject of study was determined by purposive technique. Inductive data analysis stages consist of data reduction, unitization, data category, data display, conclusion and verification. In conclusion of this study can be argued that 1) the occurrence of health disputes caused among other because: the lack of effetive communication in following up patient dissatisfaction with service and medical treatment it receives, and widespread dissatisfaction of patient to public sphere and mass media. Almost all of medical disputes handled by mediator Jogja Mediator Center (JMC) can be reconciled by psychological approaches to the disputing parties, holding caucus, motivating the parties to present themselves without legal counsel and performing legal maneuvers in the making of peace deed.
\end{abstract}

Key words : Health Disputes, Mediation, Jogja Media Center 


\section{PENDAHULUAN}

Sengketa di bidang kesehatan acapkali muncul karena tidak harmonisnya hubungan dokter atau rumah sakit dengan pihak pasien. Sengketa kesehatan yang bermula pada kesenjangan persepsi dan kepentingan antara pasien dan pihak pemberi layanan kesehatan (dokter dan atau Rumah Sakit) sering berujung pada penyelesaian dalam ranah hukum. Ada beberapa cara yang dapat dipilih pasien dalam menyelesaikan permasalahannya. Apabila mengacu pada Pasal 66 Undang-Undang No. 29 Tahun 2004 tentang Praktek Kedokteran, pasien dapat mengadukan dokter atau Rumah Sakit atas dugaan pelanggaran disiplin ke Majelis Kehormatan Disiplin Kedokteran Indonesia MKDKI, meskipun cara ini belum sepenuhnya efektif karena kurangnya sosialisasi lembaga ini sekaligus keberadaannya yang hanya ada di Jakarta, sehingga menyulitkan pasien yang berada di daerah,

Secara konvensional penyelesaian sengketa kesehatan dapat dilakukan melalui jalur pengadilan atau litigasi, yang membuat posisi para pihak yang bersengketa menjadi berseberangan, layaknya orang yang berseteru. Proses litigasi ini sebetulnya kurang menguntungkan, antara lain karena: adanya beban pembuktian, lamanya proses beracara, sidang pengadilan yang terbuka untuk umum sementara kerahasiaan merupakan hal yang diutamakan, disamping itu putusan pengadilan yang bersifat win-lose solution cenderung akan merenggangkan hubungan kedua belah pihak. Ditambah dengan berbagai resiko lain, seperti kemungkinan adanya gugatan balik atas pencemaran nama baik dan sebagainya. Selain itu makin memburuknya citra pengadilan dalam menegakkan keadilan dan kebenaran, telah mendorong masyarakat untuk mencari pilihan penyelesaian sengketa lainnya.

Penyelesaian sengketa yang efektif dan efisien dapat dilakukan dengan lebih mendayagunakan penyelesaian sengketa alternatif di luar pengadilan. Dalam UU No. 30/1999 tentang Arbitrase dan Alternatif Penyelesaian Sengketa terdapat beberapa alternatif penyelesaian sengketa, yakni: negosiasi, medi- asi, konsiliasi dan arbitrase. Mediasi sebagai salah satu alternatif penyelesaian sengketa di luar pengadilan sudah lama dipakai dalam menyelesaikan berbagai perselisihan, sengketa konsumen, sengketa pertanahan, perselisihan hubungan industrial, dan sebagainya. Ada banyak keuntungan dari mekanisme mediasi ini, antara lain: penyelesaiannya yang bersifat informal; dan diselesaikan sendiri oleh para pihak, sehingga akan sesuai dengan kemauan para pihak yang memang paling mengetahui duduk masalahnya. Mediasi tidak membutuhkan waktu yang lama, sepanjang para pihaknya beriktikad baik. Melalui mediasi hubungan para pihak yang bersengketa tetap kooperatif dan terjalin dengan baik, karena kunci dari mediasi adalah berlangsungnya musyawarah dengan bantuan seorang mediator yang berfungsi sebagai penengah yang bersifat netral.

Penyelesaian sengketa melalui mediasi kini sudah terlembagakan oleh banyak institusi. Di lembaga keuangan bank terdapat Lembaga Mediasi Perbankan Independen, di lembaga keuangan bukan bank terdapat Badan Mediasi Asuransi Indonesia (BPMAI), dan di lembaga alternatif penyelesaian sengketa konsumen dikenal dengan Badan Penyelesaian Sengketa Konsumen. Di wilayah Yogyakarta juga terdapat lembaga pelatihan sekaligus wadah profesi mediator bersertifikat yakni Jogja Mediation Center.

Namun yang disayangkan adalah belum banyak pihak yang menyelesaikan sengketanya melalui mediasi. Selama ini proses penyelesaian sengketa melalui mediasi yang dilakukan para pihak pun masih sangat rendah, yakni dibawah 5 persen. Kondisi semacam ini tentu saja memprihatinkan, karena bangsa Indonesia sebenarnya lebih mengenal pola-pola penyelesaian perselisihan secara tradisional, yaitu melalui peradilan adat atau peradilan desa yang mempunyai dasar filosofis musyawarah mufakat, dibandingkan penyelesaian yang konfrontatif seperti di Pengadilan. Di lingkungan masyarakat tradisional, nilai-nilai kooperatif dalam penyelesaian sengketa lebih mengemuka, misalnya masyarakat adat Batak mengenal forum runggun adat, Tapanuli mengenal kuria. 
Masyarakat Minangkabau memiliki lembaga kerapatan adat nagari, yang peranannya seperti mediator dan konsiliator. Demikian juga dengan budaya masyarakat Jawa, dimana konsep pembuatan keputusannya juga didasarkan pada musyawarah yang membuat kelompok mayoritas dan minoritas dapat saling sejalan dalam pemberian permufakatannya. (Sutyoso, 2006:70).

Keberadaan lembaga mediasi cenderung "tidak dianggap" oleh pihak-pihak yang bersengketa, sehingga mereka yang bersengketa cenderung menyelesaikan perselisihannya melalui pengadilan. Ini relevan dengan data dari Pengadilan Negeri Yogyakarta yang menunjukkan sangat sedikitnya perkara perdata yang dapat diselesaikan melalui mediasi. Pada tahun 2014, dari sejumlah 164 gugatan perkara perdata yang masuk ke PN Yogyakarta, hanya 20 perkara atau sekitar 11 persen saja yang dapat diselesaikan melalui mediasi. (www.pn. Yogyakarta .go.id, tanggal akses 17 Maret 2015).

Idealnya lembaga mediasi yang berintikan pada musyawarah diantara pihak yang bersengketa ini menjadi alternatif dalam mengatasi persengketaan, terutama sengketa kesehatan karena dokter dan Rumah Sakit sangat rentan terhadap pembunuhan karakter oleh media massa. Melalui mediasi inilah sengketa kesehatan diselesaikan melalui perundingan yang melibatkan pihak ketiga yang netral, dan yang kehadirannya diterima oleh pihak pasien dan Rumah Sakit. Pengambilan keputusan tidak di tangan mediator, melainkan di tangan pihak-pihak yang bersengketa. Ini relevan dengan Pasal 6 ayat (3) UU No. 30/1999 tentang Arbitrase dan Alternatif Penyelesaian Sengketa yang menyatakan bahwa dalam hal sengketa atau beda pendapat tidak dapat diselesaikan, maka atas kesepakatan pihak-pihak yang bersengketa, sengketa tersebut diselesaikan melalui bantuan seorang atau lebih penasehat ahli maupun mediator. Hasil kesepakatan penyelesaian sengketa secara tertulis adalah final dan mengikat para pihak untuk dilaksanakan dengan iktikad baik.

Tujuan penelitian dengan judul: "Media- si Dalam Penyelesaian Sengketa Kesehatan di Jogja Mediation Center" ini, yang pertama adalah untuk mengetahui penyebab timbulnya sengketa kesehatan, kedua menggambarkan upaya mediator Jogja Mediation Center dalam mendamaikan atau mencapat titik temu diantara para pihak yang bersengketa. Diharapkan hasil penelitian ini dapat memberikan wawasan mengenai eksistensi mediasi sebagai lembaga penyelesaian sengketa di luar pengadilan yang bermuara pada nilai-nilai kearifan lokal masyarakat bangsa Indonesia, dan sumbangan pemikiran terutama bagi Lembaga-lembaga Mediasi untuk mengefektifkan dan melembagakan budaya perilaku penyelesaian sengketa melalui jalan damai (dengan perantaraan mediator).

\section{METODE}

Pendekatan yuridis sosiologis dipilih untuk penelitian ini, karena menyangkut pola perilaku masyarakat yang bersengketa dalam menyelesaikan permasalahannya melalui institusi mediasi. Pendekatan yang digunakan dalam penelitian ini bersifat yuridis sosiologis karena menyangkut struktur dan substansi lembaga Mediasi di Kota Yogyakarta, dan disisi lain menyangkut bekerjanya para mediator dalam menyelesaikan sengketa kesehatan.

Subyek penelitian ini ditentukan secara purposive, dan sebagai subyek penelitian adalah mediator-mediator di Jogja Mediation Center, yang berpengalaman menyelesaikan sengketa kesehatan. Data primer penelitian ini diperoleh melalui wawancara mendalam, data sekunder diperoleh melalui studi dokumentasi. Data yang diperoleh dari penelitian ini dianalisis secara induktif. Analisis induktif ini diawali dari reduksi data, dilanjutkan dengan menyusunnya ke dalam unit-unit dan kategori yang sesuai. Selanjutnya dilakukan display atau penyajian data dan langkah terakhir adalah membuat kesimpulan serta verifikasi agar kesimpulan tidak menyimpang dari permasalahan yang diteliti. Untuk pencermatan kesahihan data dilakukan dengan cara sebagai berikut: a) penciptaan rapport yang baik dengan para informan; b) melakukan peer debriefing dengan 
teman sejawat; dan c) melakukan member check.

\section{HASIL DAN PEMBAHASAN}

Sengketa kesehatan memiliki karakter yang berbeda dengan sengketa perdata pada umumnya, seperti sengketa konsumen, sengketa pertanahan, sengketa hubungan industrial dan sebagainya. Hal ini dikarenakan sengketa kesehatan tidak hanya berdampak pada dokter sebagai pribadi saja, tetapi juga bisa berdampak pada organisasi profesi dan pada lembaga yang menaunginya (Rumah Sakit). Apabila proses penyelesaian sengketa kesehatan dilakukan melalui proses litigasi yang terbuka untuk publik, akan memberi peluang character assasination yang merugikan reputasi pemberi layanan kesehatan. Mempertimbangkan karakter yang khas dari profesi kedokteran ini, maka perlu dicari alternatif penyelesaian sengketa kesehatan di luar pengadilan.

Mediasi merupakan pendekatan non litigasi dalam penyelesaian sengketa yang diakui oleh hukum positif di Indonesia yang ditempuh melalui pendekatan kekeluargaan, mengedepankan prinsip kemanusiaan dan keadilan dalam rangka menjaga hubungan baik untuk mengakhiri sengketa yang ada. Mediasi layak dipilih karena sifatnya yang saling menguntungkan (mutual winning). Selain itu prosesnya yang tertutup telah mampu menjaga kerahasiaan para pihak yang bersengketa, dan proses musyawarah untuk pengambilan keputusan bersama, mampu menempatkan kesetaraan posisi tawar antara pihak pasien dengan dokter atau rumah sakit yang tersandung sengketa. Kesepakatan bersama yang diperoleh melalui mediasi untuk mengakhiri sengketa kesehatan, akan dituangkan dalam nota perdamaian ataupun akta perdamaian yang bersifat final dan binding

Penyebab Sengketa Antara Pasien dengan Pemberi Layanan Kesehatan (sengketa kesehatan)

Pada dasarnya hubungan antara pelayanan kesehatan (dokter dan Rumah Sakit) dengan pasien adalah hubungan yang didasarkan pada kepercayaan. Pasien percaya terha- dap kemampuan dokter yang akan berupaya secara maksimal untuk menyembuhkan penyakit yang dideritanya. Satu hal yang terlupakan oleh pasien adalah pelayanan kesehatan dilakukan berdasarkan keilmuan kedokteran, dan ilmu kedokteran bukanlah ilmu pasti layaknya matematika yang hasilnya sudah bisa diprediksi di awal perhitungan. Besarnya kepercayaan yang terbangun inilah yang seringkali berbuah kekecewaan ketika harapan sembuh tidak terwujud pasca mendapatka layanan medik. Malah penyakit berkembang menjadi parah, atau muncul efek samping dari pengobatan atau tindakan medik yang dilakukan, misalnya pasien menjadi cacat atau berujung kematian. Ini bisa berdampak pada tidak harmonisnya hubungan dokter dengan pasien, karena pasien dan keluarganya menganggap telah terjadi kelalaian tindakan medik atau malpraktek medik. Faktanya, pasien cenderung mempermasalahkan hasil pelayanan kesehatan dengan mengabaikan prosesnya, sementara dalam hukum kesehatan menegaskan bahwa dalam memberikan pelayanan, tenaga kesehatan hanya bertanggung jawab atas upaya yang dilakukan (Inspanning Verbintennis) dan tidak menjamin hasil akhir (Resultalte Verbintennis).

Semula ketergantungan yang besar kepada dokter telah memposisikan pasien dan masyarakat dalam posisi tawar yang tidak seimbang. Namun mengacu pada UndangUndang Nomor 23 Tahun 1992 tentang Kesehatan dan Undang-Undang Nomor 29 tahun 2004 tentang Praktek Kedokteran, dapat dikemukakan bahwa hubungan antara dokter dan pasien tidak lagi bersifat paternalistik, melainkan diposisikan sejajar. Dalam dua undang-undang tersebut ditegaskan bahwa dokter dan pasien mempunyai hak dan kewajiban yang harus saling dihormati. Dokter berhak memperoleh perlindungan hukum dalam melaksanakan tugas sesuai dengan profesinya, sedangkan kewajibannya adalah mematuhi standar profesi dan menghormati hak pasien. Pasien mempunyai hak-hak yang bersifat mendasar, antara lain adalah hak: (a) mendapatkan informasi, (b) memberikan persetujuan terhadap tindakan medik atau informed consent, (c) atas ra- 
hasia kedokteran, serta (d) untuk memperoleh pendapat kedua atau second opinion. Konflik antara dokter dengan pasien bisa dicegah apabila dokter mengindahkan kewajibannya dan mengakomodasi hak pasien. Menurut Hariyani (2005:11), konflik adalah sebuah situasi dimana dua pihak atau lebih dihadapkan pada perbedaan kepentingan. Sebuah konflik berubah atau berkembang menjadi sengketa apabila pihak yang merasa dirugikan telah menyatakan rasa tidak puasnya atau keprihatinannya baik secara langsung kepada pihak yang dianggap sebagai penyebab kerugian atau kepada pihak lain. Jadi konflik dapat berubah atau berlanjut menjadi sengketa, yang berarti pula bahwa sebuah konflik antara pasien dengan dokter atau Rumah Sakit yang tidak terselesaikan akan berubah menjadi sengketa kesehatan. Ini relevan dengan ketentuan Pasal 66 ayat (1) Undang-Undang Nomor 29 Tahun 2004 tentang Praktek kesehatan, yang secara tersirat menyebutkan bahwa sengketa kesehatan adalah sengketa yang terjadi karena kepentingan pasien dirugikan oleh tindakan dokter atau dokter gigi yang menjalankan praktik kedokteran. Dengan demikian sengketa kesehatan merupakan sengketa yang terjadi antara pengguna pelayanan medik dengan pelaku pelayanan medik dalam hal ini antara pasien dan dokter berikut sarana kesehatan

Sengketa kesehatan tidak bisa dicarikan jalan pemecahannya, apabila tidak diketahui penyebabnya. Tidak bisa diingkari bahwa profesi kedokteran saat ini seperti di atas cawan mikroskop, karena menjadi pusat perhatian dan banyak dikritisi oleh masyarakat serta media massa. Beberapa hal yang sering menjadi penyebab sengketa kesehatan, antara lain karena pasien dan masyarakat mempunyai persepsi yang kurang pas terhadap layanan kesehatan.

Hal ini relevan dengan pendapat Suryono (2010:2) yang mengemukakan "kemajuan teknologi dan bioteknologi dalam bidang kedokteran memberikan harapan positif bagi peningkatan kualitas pelayanan kesehatan di Indonesia. Dengan teknologi diagnose dapat dideteksi sedini mungkin dengan presisi yang maksimal, begitu juga dengan teknologi hasil perawatan yang di capai bisa optimal dengan resiko atau dampak negative yang minimal. Namun teknologi dan bioteknologi dalam pelayanan kesehatan hanya sebatas memberikan upaya maksimal dan minimalisasi dampak negative belum bisa sampai pada tataran kepastian hasil".

Hal tersebut di atas semestinya dipahami oleh dokter maupun oleh pasien. Namun dokter, terlebih lagi pasien kadang mudah terjebak dalam nuansa promosi dari keunggulan suatu teknologi dalam pelayanan kesehatan yang ditawarkan sehingga timbul harapan bahwa dengan teknologi kedokteran tersebut semuanya bisa dipastikan, bisa disembuhkan. Yang memprihatinkan, kadang untuk kepentingan promosi, tak jarang pihak lembaga pemberi layanan kesehatan (dokter atau Rumah Sakit) menginformasikan keuntungan teknologi yang digunakan secara berlebihan tanpa adanya informasi mengenai kerugian atau dampak yang mungkin muncul dari penggunaanya. Pemberian informasi yang tak berimbang inilah yang sering menimbulkan ketidakpuasan atau kekecewaan di kalangan pasien dan keluarganya. Dan ketika kekecewaan serta ketidakpuasan pasien tersebut tidak di sertai komunikasi yang efektif, serta pasien tidak memperoleh informasi yang jelas dari pihak pemberi layanan kesehatan, ketidakpuasan tersebut berkembang menjadi sengketa kesehatan.

Berdasarkan pada tahapannya, sengketa kesehatan bisa muncul pada tahap pra perawatan, saat perawatan maupun pasca perawatan Pada tahap pra perawatan, ketidak puasan dapat ditengarai, misalnya saat penerimaan awal di Rumah Sakit (saat pendaftaran, Kegawat Daruratan dan sebagainya), karena pelayanan yang tidak ramah, tidak cepat, waktu menunggu yang lama sehingga pasien dan keluarganya merasa ditelantarkan. Sedangkan pada tahap perawatan, ketidak puasan pasien yang berujung pada sengketa dapat ditengarai dari banyaknya komplain dan keluhan masyarakat yang masuk ke area publik, antara lain: (1) penggunaan secara berlebihan teknologi atau alat canggih kedokteran di 
Rumah Sakit yang tidak jelas urgensinya, (2) meninggal/cacatnya pasien akibat kegagalan tindakan medik, (3) pengobatan ala kadarnya (under treatment substandard) pada pasien tidak mampu, (4) perpanjangan length of stay pasien VIP untuk penambahan penghasilan Rumah Sakit, (5) Melakukan pemeriksaan atau pengobatan berlebihan yang tidak sesuai dengan kebutuhan pasien, (6) pelaksanaan futilisasi medis (kesia-siaan medis) bagi penyakit yang tidak bisa sembuh lagi. Sengketa pasca perawatan bisa muncul karena pembiayaan yang besar, atau hasil dari perawatan yang tidak sesuai dengan harapan, karena pasien tidak kunjung sembuh. Munculnya efek samping dari tindakan medis, sehingga pasien menjadi cacat bahkan sampai terjadi kematian dan tindakan dokterlah yang diduga sebagai penyebabnya. Dari ketidakpuasan tersebut kemudian berkembang menjadi sengketa kesehatan.

Menurut Suryono (2010:3) penyelesaian sengketa tersebut seharusnya dilakukan secara berjenjang, mengingat profesi tenaga kesehatan dan lembaga yang menaunginya (Rumah Sakit) ini rentan terhadap pembunuhan karakter oleh media massa atau rentan terhadap pemerasan oleh oknum yang tak bertanggungjawab. Pada tahap pertama, gejala awal ketidakpuasan muncul dengan ditandai oleh pasien melayangkan keluhan secara tertulis ke pihak Rumah Sakit. Pada tahap ini sebaiknya pihak rumah sakit melalui bagian humas segera merespon keluhan tersebut dengan pemberian klarifikasi atas permasalahan tersesbut, sehingga pihak pengadu merasa puas dan terselesaikan permasalahannya. Pada tahapan kedua, apabila sengketa telah meluas yang dapat ditengarai dari adanya surat ketidakpuasan pelayanan yang ditujukan ke RS tersebut ditembuskan ke media massa, ke LSM atau ke Ombudsman, serta melibatkan pihak ketiga, misalnya kuasa hukum. Pada tahap ini diperlukan adanya penengah yang dianggap netral untuk membantu menyelesaikan sengketa tersebut. Pada tahap ketiga, jika laporan sengketa kesehatan disaampaikan pada pihak yang berwajib (kepolisian, atau pengadilan) maka bila penyelesaian sengketa secara tertutup masih di inginkan oleh pihak dokter atau Rumah Sakit, maka keberadaan mediator bersertifikat menjadi sangat diperlukan. Bila proses ini gagal, maka penyelesaian sengketa melalui jalur litigasi atau pengadilan tidak bisa dihindarkan lagi.

Bagi pihak dokter dan Rumah Sakit, penyelesaian sengketa kesehatan melalui jalur pengadilan berarti mempertaruhkan reputasi yang telah dicapainya dengan susah payah, dan dapat menyebabkan kehilangan nama baik. Meskipun belum ada putusan pengadilan yang memvonis dirinya, nama baik dokter atau Rumah Sakit sudah terkesan buruk karena sudah dipublikasikan secara terbuka di media massa, dan diberitakan telah melakukan kesalahan medik ataupun malpraktek medik. Imbasnya adalah tingkat kepercayaan masyarakat terhadap dokter atau Rumah Sakit akan turun. Penyelesaian sengketa kesehatan melalui mediasi, dianggap paling ideal karena proses penyelesaiannya bersifat tertutup dan tidak terpublikasikan, sehingga akan memberikan perasaan nyaman, dan aman kapada para pihak, dan kekhawatiran terbukanya rahasia dan nama baik yang sangat dibutuhkan oleh dokter maupun sarana pelayanan kesehatan dapat dihindari. Disamping itu para pihak yang bersengketa dipertemukan secara langsung yang memungkinkan dialog terbuka, sehingga titik temu yang menguntungkan para pihak kemungkinan besar dapat tercapai.

\section{Proses Mediasi di Jogja Mediation Center}

Jogja Mediation Center (JMC) merupakan wadah profesi mediator bersertifikat yang telah menyelesaikan Pendidikan Mediasi dari Universitas Gadjah Mada. Sebagai asosiasi Mediator yang didirikan di Yogyakarta, JMC diharapkan dapat berkiprah secara regional maupun nasional. Mediator JMC bertugas menjembatani pihak pihak bersengketa untuk bisa menyelesaikan kasus sengketa perdata, termasuk sengketa kesehatan, di luar sidang pengadilan dengan prinsip mutual winning. Semua pihak tidak ada yang merasa kalah atau dikalahkan karena setiap sengketa pasti diawali dengan ketidaksengajaan bahwa apa yang dilakukan merugikan pihak lain. Jadi, ketika 
dikembalikan kepada esensi hubungan antar pihak sebelumnya, akhirnya kedua belah pihak akan sepakat menyelesaikan sengketanya secara damai.

Berbeda dengan mediasi di pengadilan yang diwajibkan oleh majelis hakim, mediasi di JMC dilaksanakan atas kehendak para pihak. Dengan kata lain setelah para pihak menemui jalan buntu dalam menyelesaikan sengketanya, pihak pasien maupun dokter dan Rumah Sakit bersepakat untuk meminta bantuan penengah dari JMC dalam menyelesaikan sengketa mereka. Adapun langkah-langkah penyelesaian sengketa di JMC, antara lain adalah:

1. Penyampaian kehendak ke JMC, pemilihan mediator, penentuan jadwal dan tempat pertemuan mediasi

Sebelum pihak yang bersengketa datang ke JMC, mereka telah gagal melakukan negosiasi, dan kemudian bersepakat untuk meminta bantuan mediator JMC untuk menyelesaikan permasalahan mereka

2. Deskripsi situasi dan identifikasi perkara Dengan mempertemukan dan mendengarkan penjelasan pihak pasien dengan pihak dokter yang bersengketa, mediator dapat menemukan pokok masalah yang sebenarnya terjadi yang akan menjadi fokus dalam proses mediasi.

3. Pemetaan masalah \& membingkai ulang permasalahan.

Mediator merumuskan kembali permasalahan dan menyampaikan hasil rumusannya kepada para pihak untuk memperoleh tanggapan. Dilanjutkan dengan membuat pemetaan masalah untuk mengetahui prioritas permasalahan.

\section{Menghasilkan alternatif-alternatif penyelesaian sengketa}

Tahap ini bertujuan untuk menghasilkan atau merumuskan tuntutan-tuntutan dan alternatif penyelesaian terhadap permasalahan yang ada

5. Evaluasi \& Pemilihan Alternatif-alternatif Tuntutan para pihak dan alternatif penyelesaian sengketa yang telah digeneralisir, kemudian disusun menjadi serangkaian daftar alternatif yang selanjutnya akan di- analisis oleh para pihak yang bersengketa. Para pihak diberi kesempatan untuk membahas dan mengkonsultasikan alternatifalternatif tersebut kepada pihak lain lain, seperti notaris, pengacara ataupun berkonsultasi kepada mediator.

6. Melakukan Kaukus dengan para Pihak Tindakan yang sering dilakukan oleh para mediator JMC ialah melakukan kaukus dengan para pihak. Kaukus ini merupakan pertemuan antara mediator dengan salah satu pihak tanpa dihadiri oleh pihak yang lainnya atau disebut juga sebagai pertemuan terpisah.

\section{Merumuskan kesepakatan}

Pada tahap terakhir ini, para pihak melakukan negosiasi final, yaitu klarifikasi ketegasan para pihak mengenai alternatif-alternatif bagi penyelesaian sengketa yang terjadi diantara mereka. Tercapainya kesepakatan final antara para pihak yang bersengketa, merupakan putusan untuk menyelesaikan dan mengakhiri sengketa. Dalam merumuskan Kesepakatan Perdamaian, Mediator wajib memastikan kesepakatan tersebut tidak memuat ketentuan yang: a) bertentangan dengan hukum, ketertiban umum, dan/ atau kesusilaan; b) merugikan pihak ketiga; atau c) tidak dapat dilaksanakan.

Kesepakatan tersebut akan dirumuskan mediator dalam nota perdamaian yang berbentuk perjanjian di bawah tangan (gentlemen agreement). Meskipun secara yuridis, nota perdamaian tersebut belum berkekuatan eksekutorial yang sama seperti putusan pengadilan, tapi para pihak terikat untuk melaksanakannya (asas pacta sunt servanda). Apabila dikehendaki para pihak, mediator akan mengajukan nota perdamaian tersebut ke Pengadilan Negeri Yogyakarta untuk ditetapkan menjadi akta perdamaian (pasal 27 ayat 2 Peraturan Mahkamah Agung No. Tahun 2016 tentang Mediasi di pengadilan).

Keberhasilan Mediator Jogja Mediation Center Mendamaikan Sengketa Kesehatan

Dapat dikemukakan bahwa hampir semua sengketa kesehatan yang ditangani dan 
dimediasi oleh Jogja Mediator Center dapat diselesaikan atau dapat didamaikan. Sejauh ini tidak ada perselisihan yang ditangani JMC yang terpaksa berlanjut ke jalur litigasi. Keberhasilan mendamaikan tersebut disamping karena strategi mediator JMC dalam memediasi, juga karena karakteristik para pihak yang mengajukan permintaan mediasi di JMC, bukanlah tipe penyuka konflik. Selain itu pada umumnya dokter dan Rumah Sakit cenderung ingin bekerja tenang, menjaga reputasinya, tidak ingin berperkara dan cenderung untuk berdamai. Keberhasilan mediasi juga harus didukung oleh beberapa persyaratan antara lain adalah: a) para pihak mempunyai posisi tawar yang setara, b) para pihak mempertimbangkan kelangsungan relasi di masa yang akan datang, c) para pihak tidak mempunyai bibit permusuhan yang lama dan mendalam bahwa mediasi akan berjalan dan mencapai titik temu (Sulistiono, 2008:88).

Semua mediator di JMC memiliki keterampilan dan teknik-teknik perundingan, yang antara lain meliputi: a) kemampuan mendengar aktif dan efektif, b) kemampuan berempati, c) terampil berunding dan bernegosiasi, d) memfasilitasi perundingan, kemampuan mengatasi emosi para pihak, dan mengatasi jalan buntu, e) ketrampilan berkomunikasi verbal dan non verbal, f) terampil dalam membingkai ulang, dan merefleksikan kepada pihak pembicara untuk memperoleh tanggapan, g) memiliki toleransi yang tinggi terhadap emosi, i) ketrampilan untuk merumuskan ulang hal-hal penting dan identifikasi perasaan yang terungkap. Meskipun semua mediator memiliki ketrampilan dan berpengalaman memediasi sengketa, tapi tidak semua mediator JMC berkompeten untuk memediasi sengketa kesehatan. Mediator yang tepat untuk menangani sengketa medis haruslah mediator yang memiliki pengetahuan memadai tentang dunia medis, sekaligus pengetahuan tentang hukum. Apabila mediator tidak memahami istilahistilah kedokteran, akan sulit baginya memahami penjelasan dari pihak pelaksana layanan kesehatan, yang berdampak pada terhambatnya mediator menterjemahkan dan mentrans- fer informasi dari dokter kepada pasien.

Dalam proses penyelesaian sengketa kesehatan, para mediator JMC memiliki beberapa strategi untuk mendamaikan pihak yang bersengketa, antara lain adalah dengan mengadakan pendekatan psikologis kepada para pihak, semaksimal mungkin mengadakan kaukus, memotivasi para pihak untuk menghadiri proses mediasi, serta melakukan pemetaan masalah.

\section{Pendekatan psikologis terhadap pihak- pihak yang berkonflik.}

Umumnya pihak yang bersengketa, utamanya pihak pasien memendam emosi, menyimpan perasaan marah sekaligus rasa takut dan perasaan lainnya kepada pihak dokter, sehingga pendekatan psikologis menjadi garapan pertama para mediator JMC. Yang dilakukan dengan berbagai cara, antara lain:

\section{a. Mengelola emosi para pihak yang bersengketa}

Emosi pasien dan dokter yang bersengketa sering menjadi salah satu sumber permasalahan teknis selama mediasi. Untuk meredam emosi, mediator berusaha menciptakan atmosfer yang mengedepankan dialog, analisis masalah, dan penyelesaian masalah. Fakta ini menjadi tantangan tersendiri bagi mediator JMC , sehingga dalam mengelola emosi para pihak, aspek-aspek yang dipertimbangkan mediator antara lain: kompleksitas komunikasi yang berbau emosi dan posisi tawar antara pasien dengan dokter yang cenderung tidak setara, yang berpotensi menjadikan konflik semakin panas.

\section{b. Mengatur pertemuan bersama}

Pertemuan bersama adalah kesepakatan untuk bertemu antara pihak pasien dengan dokter yang berkonflik disertai oleh mediator JMC pasca pertemuan terpisah (kaukus). Pertemuan bersama ini merupakan tindak lanjut dari pertemuan terpisah yang dilakukan di awal mediasi. Pertemuan bersama merupakan indikasi keseriusan semua pihak yang berkonflik untuk menjalankan semua hasil kesepakatan sebagai 
implikasi penyelesaian konflik dengan cara sedamai mungkin

\section{Mediator memfasilitasi Kaukus dengan para Pihak}

Kaukus merupakan pertemuan antara mediator dengan salah satu pihak tanpa dihadiri oleh pihak yang lainnya atau disebut juga sebagai pertemuan terpisah. Bagi mediator JMC, kaukus merupakan tindakan urgen yang harus dilakukan kala memediasi sengketa kesehatan, karena kaukus terutama berfungsi untuk mengatasi kebuntuan komunikasi, atau mediator menangkap kesan salah satu pihak, misalnya pasien, seperti tidak bebas atau tertekan. Dalam kegiatan kaukus, mediator dapat melakukan beberapa kegiatan, seperti:

a. mediator dapat melakukan pendekatan persuasive kepada salah satu pihak, menekan ego salah satu pihak sehingga kebuntuan komunikasi dapat terurai;

b. dalam pertemuan yang dilakukan secara terpisah antara mediator hanya dengan salah satu pihak saja, diharapkan pihak tersebut dapat menyalurkan emosinya secara bebas, tanpa membahayakan kemajuan proses mediasi yang sedang berlangsung

c. melalui kaukus sangat memungkinkan bagi salah satu pihak untuk mengungkapkan kepentingan - kepentingan tersembunyi ataupun ganjalan-ganjalan yang tidak ingin diungkapkan di hadapan mitra rundingnya.

d. mediator JMC dapat membantu pihak tersebut untuk mengembangkan dan menganalisis pilihan yang lain secara individual, disamping itu melalui kaukus memungkinkan mediator untuk mencari informasi tambahan yang berkaitan dengan para pihak dan pokok sengketa.

\section{Mengharuskan kehadiran pihak yang} bersengketa tanpa kuasa hukumnya

Pasien dan dokter yang terlibat dalam sengketa kesehatan ini merupakan pihak yang mengalami sendiri peristiwa tersebut, sehingga merekalah yang paling tahu apa yang mereka kehendaki. Sehingga intervensi dan kehadiran kuasa hukum, terkadang membuat permasalahan menjadi lebih ru- mit dan malah menjauh dari titik temu. Dengan pertimbangan tersebut, mediator JMC memotivasi dan "mengharuskan" para pihak yang bersengketa untuk menghadiri sendiri proses mediasi dan tidak mewakilkan kepada kuasa hukumnya. Dikemukakan oleh mediator JMC, kuasa hukum cenderung tidak mendukung proses mediasi, karena para kuasa hukum terkadang mempunyai kepentingan sendiri (vested interest).

Apabila dianalogkan proses mediasi di pengadilan, dimana yang menghadiri mediasi adalah kuasa hukum saja sedangkan pihak-pihak yang bersangkutan justru tidak hadir. Situasi tersebut sangat berpengaruh pada pelaksanaan mediasi dan tercapainya perdamaian, karena kuasa hukum cenderung tidak mendukung, dan acapkali berkeberatan terhadap kaukus yang ditawarkan oleh mediator. Ditengarai perilaku kuasa hukum tersebut ada kaitannya dengan masalah pemberian honorarium, yang memiliki beberapa pola honorarium, sebagai berikut: a) kuasa hukum mempunyai klien tetap dan menerima honor tetap, b) kuasa hukum menerima honor berdasarkan penanganan kasus hingga selesai, c) kuasa hukum menerima honor dari klien berdasarkan jam kerja atau frekuensi kunjungan ke persidangan.

Pola pemberian honorarium tersebut dapat mempengaruhi sikap pengacara atau kuasa hukum. Bukan tidak mungkin pengacara bersikap negatif atau bersikap tidak mendukung terhadap proses mediasi, karena jika kasus yang ditanganinya selesai dengan cepat, maka honor yang diterima pengacara tersebut menjadi lebih sedikit jumlahnya. Hal ini selaras dengan pendapat Adi Nugroho (2009: 208), yang menjelaskan bahwa para advokat yang menerima honorarium berdasarkan jam kerja atau frekuensi kunjungan ke persidangan cenderung bersikap negatif terhadap mediasi, karena jika kasus yang ditanganinya dapat diselesaikan secara cepat melalui perdamaian, maka mereka akan menerima honor lebih kecil. 
Para pengacara cenderung mengarahkan para pihak agar meneruskan sengketanya ke proses litigasi yang mana membutuhkan frekuensi kedatangan ke pengadilan lebih sering dengan berbagai alasan misalnya posisi mereka dalam sengketa tersebut lebih menguntungkan sehingga dalam litigasi nantinya akan memenangkan perkara. Hal inilah yang menghambat para pihak untuk menghasilkan perdamaian.

Dengan pertimbangan lebih sulit dan lebih lamanya waktu yang diperlukan untuk mencapai titik temu apabila mediasi diwakilkan kepada kuasa hukum, maka JMC mengambil kebijakan untuk "mengharuskan" para pihak hadir sendiri dalam proses mediasi.

\section{Manufer Jogja Mediation Center dalam penyusunan nota perdamaian}

Agar para pihak mempunyai bukti atas kesepakatan yang diperoleh untuk mengakhiri perselisihannya, serta terikat untuk melaksanakan kesepakatannya, mediator wajib menuangkan dalam nota perdamaian. Nota perdamaian atau kesepakatan perdamaian tersebut merupakan perjanjian di bawah tangan dan memuat gentlemen agreement. Agar nota perdamaian tersebut mempunyai kekuatan eksekutorial, dapat diajukan ke Pengadilan Negeri untuk ditetapkan menjadi akta perdamaian. Ini sesuai dengan ketentuan Pasal 36 ayat (1) Peraturan Mahkamah Agung No. 1 tahun 2016 tentang Prosedur Mediasi di Pengadilan yang menyatakan "Parapihak dengan atau tanpa bantuan Mediator bersertifikat yang berhasil menyelesaikan sengketa di luar Pengadilan dengan Kesepakatan Perdamaian dapat mengajukan Kesepakatan Perdamaian kepada Pengadilan yang berwenang untuk memperoleh Akta Perdamaian dengan cara mengajukan gugatan".

Dengan ditetapkan menjadi akta perdamaian, maka nota perdamaian tersebut akan berkekuatan hukum sebagaimana putusan hakim yang telah memperoleh kekuatan hukum tetap, dan berkekuatan eksekutorial (executorial kracht). Sehingga apabila salah satu pihak tidak mentaati pemenuhan kewajiban yang ditentukan secara sukarela dalam perjanjian perdamaian tersebut, maka dapat minta eksekusi kepada Pengadilan Negeri dan atas permintaan itu, Ketua Pengadilan Negeri menjalankan eksekusi sesuai dengan ketentuan Pasal 195 HIR.

Namun penetapan akta perdamaian di PN ini sering kali memperoleh hambatan. Antara lain, karena terkadang ada klausul-klausul yang dikurangi atau dihapus oleh hakim Pengadilan Negeri Yogyakarta, atau hakim PN Yogyakarta menambahkan klausula tertentu. Tidak dicantumkannya secara keseluruhan klausulklausul ke dalam akta perdamaian, sering memicu masalah baru diantara para pihak, yang malah membuat perdamaian tersebut menjadi tidak bisa tuntas seperti keinginan para pihak saat proses mediasi.

Kekhawatiran bahwa nota perdamaian tersebut kurang mempunyai kekuatan mengikat ditepis dengan meyakinkan para pihak, bahwa dilaksanakannya isi kesepakatan tersebut bergantung sepenuhnya pada iktikad baik para pihak. Selain itu Jogja Mediation Center juga telah melakukan satu loncatan (manufer) hukum, yakni dengan mengadakan kerja sama dengan Notaris. Kesepakatan atau perjanjian perdamaian yang telah dicapai oleh pihak pasien dan Rumah Sakit, untuk selanjutnya dibawa kepada Notaris. Perjanjian perdamaian tersebut akan dituangkan dalam akta notariil. Akta perdamaian yang dibuat oleh notaris tersebut merupakan akta otentik. Dengan dituangkannya nota perdamaian tersebut dalam akta notaris, maka akta perdamaian tersebut merupakan suatu bukti yang sempurna (full evident) tentang kesepakatan-kesepakatan yang ada di dalamnya. Oleh notaris, nota perdamaian tersebut akan dituangkan dalam Akta Perdamaian yang berisi pelaksanaan (eksekusi) isi dari klausula-klausula dalam nota perdamaian. Dengan demikian maka nota perdamaian yang telah disepakati serta dibuat oleh para pihak melalui proses mediasi, menjadi terlaksana secara kekeluargaan dan tuntas. Sehingga diantara para pihak tersebut sudah tidak ada lagi ganjalan atau sengketa yang masih tersisa dan tidak terselesaikan. 


\section{SIMPULAN DAN SARAN}

Dipenghujung tulisan ini dapat dikemukakan bahwa timbulnya sengketa kesehatan, antara lain disebabkan karena kekecewaan dan ketidakpuasan pasien atas layanan dan tindakan medis yang diterima pada tahap pra perawatan, saat perawatan, atau pasca perawatan. Ketidakpuasan pasien akhirnya meluas ke ranah publik, dan dipublikasikan sebagai kelalaian tindakan medik atau malpraktek medik, yang akhirnya berkembang menjadi sengketa kesehatan tatkala pihak pelaksana layanan kesehatan tidak melakukan klarifikasi dan tidak mengkomunikasikan mekanisme tindakan medis secara memadai yang mampu memahamkan pihak pasien. Mengingat karakter profesi dokter dan Rumah Sakit yang rentan terhadap pembunuhan karakter oleh media massa serta rentan terhadap pemerasan oleh oknum yang tak bertanggungjawab, maka mediasi merupakan salah satu alternatif untuk menyelesaikan sengketa kesehatan di atas.

Jogja Mediation Center merupakan wadah mediator bersertifikat yang berpengalaman menangani banyak sengketa kesehatan. Hampir semua sengketa kesehatan dapat didamaikan, sehingga sejauh ini tidak ada sengketa kesehatan yang ditangani mediator JMC yang berlanjut ke jalur litigasi. Mediator JMC mensiasati penyelesaian sengketa kesehatan dengan mengadakan pendekatan psikologis kepada para pihak yang bersengketa serta memfasilitasi kaukus para pihak untuk penggalian ganjalan-ganjalan dan kepentingan yang tersembunyi. Selain itu kehadiran para pihak yang bersengketa, tanpa dampingan kuasa hukum yang terkadang memiliki vested interest, juga menjadi fokus mediator JMC untuk mencapai titk temu. Disamping itu mediator JMC telah melakukan manufer hukum dalam penetapan nota perdamaian menjadi akta perdamaian yang bersifat final dan binding dengan cara melakukan kerjasama dengan Notaris tanpa melalui proses gugatan ke Pengadilan Negeri.

\section{UCAPAN TERIMA KASIH}

Penulis mengucapkan terima kasih kepada berbagai pihak yang telah membantu penelitian ini. Penulis juga mengucapkan terima kasih kepada dewan redaksi Jurnal Socia atas kesempatan yang diberikan sehingga paper ini dapat diterbitkan pada Jurnal Socia FIS UNY serta telah melakukan review sebelumnya.

\section{DAFTAR PUSTAKA}

Adi Nugroho, Susanti. 2009. Mediasi Sebagai Alternatif Penyelesaian Sengketa. Jakarta: Telaga Ilmu Indonesia

Hariyani, S. 2005. Sengketa Medik - Alternatif Penyelesaian Peselisihan Antara Dokter dengan Pasien. Jakarta: Diadit Media.

Peraturan Mahkamah Agung Nomor 1 Tahun 2016 tentang Prosedur Mediasi di Pengadilan

Suryono. 2010. Penyelesaian sengketa dugaan malpraktek tenaga kesehatan, Pertemuan IBI Yogyakarta:RS Sardjito.

Sulistiono, Adi. 2008. Eksistensi dan Penyelesaian Sengketa HaKI. Surakarta: Sebelas Maret University Press.

Sutyoso, B. 2006. Penyelesaian Sengketa Bisnis. Yogyakarta: Citra Media.

Undang-Undang RI Nomor 23 Tahun 1992 tentang Kesehatan

Undang-Undang RI Nomor 29 Tahun 2004 tentang Praktek Kedokteran

Undang-Undang RI Nomor 30 Tahun 1999 tentang Arbitrase dan Alternatif Penyelesaian Sengketa

www.pn.Yogyakarta.go.id, tanggal akses 17 Maret 2015 